\author{
Andrijana Aničić" \\ University of Belgrade \\ Faculty of Philology \\ Belgrade, Serbia
}

\title{
THE COMMON LANGUAGE OF DISCIPLINE: NESTING PEDAGOGY AND ALTERNATIVE SUBJECT POSITIONS IN POWER IN SERBIA
}

\begin{abstract}
This paper explores the complexity of the discourses surrounding the choice of Ana Brnabić as Serbian PM in the context of Serbia's EU accession process. In my analysis I focus on several key concepts: leveraged pedagogy, homonationalism and sexual citizenship. I rely on recent work by scholars who have proposed and explored the dynamic interplay of these concepts (Kahlina 2013; Butterfield 2013; Kulpa 2014, Kahlina 2014). I highlight structural parallels between the disciplinary mechanisms that characterize both wider discourses of Europeanisation and the rhetoric of pro-European political elites in Serbia. My central argument is that the "morphosyntactic" parallels between the two discourses coalesce into a common language of discipline that produces an alternative subject position in power whose agency is essentially cancelled. In conclusion, I propose that the similarities between the disciplining regimes of the two discourses could be understood in terms of a "nesting pedagogy." For the purposes of this essay, I use this term to denote disciplinary regimes emanating from the EU which, as they cascade south-eastwards toward the bloc's periphery, produce nested hierarchical binaries marked by the pedagogic and infantilizing treatment of the Other.
\end{abstract}

Key words: language of discipline, homonationalism, sexual citizenship, nesting pedagogy

E-mail address: andrijananicic@yahoo.com 


\section{Introduction}

By a parliamentary majority vote on 29 June 2017, Serbia elected the first lesbian Prime Minister in its history. The former Minister of Public Administration and Local Self-Government, Ana Brnabić, had been nominated by President Aleksandar Vučić to succeed him as Prime Minister (PM). After the Serbian Parliament (in which the ruling Serbian Progressive Party (SNS) led by Aleksandar Vučić holds an overwhelming majority) endorsed the nomination, Ana Brnabić pledged an oath to the National Assembly, thus becoming the fifth gay head of government in European history after Iceland, Belgium, Luxembourg and recently Ireland. The reactions to a lesbian Prime Minister in EU-hopeful Serbia have ranged from celebratory to sceptical and highly suspicious. The choice of Ana Brnabic as the leader of the Serbian Government was lauded in some media as a sign of Serbia's progression to democratisation, modernity and social equality, "accompanied by the sound of glass ceilings being shattered around her" (Wintour 2017). The other end of the media spectrum voiced suspicions of the appointment as an example of "pinkwashing" and as a marketing trick (Da se zna! 2017; Stojanović 2017; Dinić 2017) on the part of political elites with an equivocal stand on sexual politics who wish to "endear themselves to the European Union" (Juras 2009, as cited in Butterfield 2013: 20).

A peculiar incident in a parliamentary session in late 2016 illustrates the ambiguous situation in which the Serbian political elites are caught. The incident featured Aleksandar Martinović, leader of the parliamentary caucus of the Serbian Progressive Party, and his party colleague and President of the National Assembly, Maja Gojković, both ex-MPs of the far-right Serbian Radical Party, from which the ruling SNS split in 2008, when they decided to pursue a pro-European agenda. Countering the accusations of opposition MPs, Martinović ${ }^{2}$ issued a series of homophobic statements in which he decidedly opposed presenting homosexuality as

1 Pinkwashing is a term used to denote state practices of covering up wider discriminatory policies and violation of rights by selective and transparent gestures of respect for LGBT rights. It is often attached to Israel's state policy of gay-friendliness that "deflects attention from" or legitimates its occupation of Palestine. (Puar 2013: 32)

2 Several months later, in June 2017, before the scheduled parliamentary vote on the appointment of Ana Brnabić, Martinović said that the choice of Brnabić is "in Serbia's best interest", and that those who do not vote in favour of Vučić's proposal will thus declare themselves to be against the President (B92 2017a). 
equal to heterosexuality in a high school textbook to loud approval from his party colleagues. After Maja Gojković's unsuccessful attempts to stop him from venturing further into his elaboration of normal and abnormal sexual practices, she finally turned his microphone off and a protracted silence ensued, filled with the awkward gestures she used to explain discreetly to her party colleague why she had resorted to such a "radical", disciplining move. Forgetting that she hadn't turned off her own microphone, in a low voice she said defeatedly: "I can't let him go on, Ana is here!"

Ana's presence seems to serve as a corrective mechanism for silencing the statements that would, in "regular" circumstances, be issued freely and without interruption. The semantics of the prolonged silence reveals a wider range of complex issues facing EU-aspiring Serbia that have been pinkwashed by the presence of an openly gay government official, who in this situation, and as will be evident in the discussion that follows, is relegated to a position of a silent presence. This should not be too surprising. The appointment of the first lesbian Prime Minister of Serbia comes from political actors who have recently embraced European values and recognised the EU as the desired destination, ostensibly relinquishing their nationalist political past and dismissing political platforms in which nationalism, homophobia and patriotism are mutually constitutive (Moss 2014). Therefore, the complexity of the choice of Ana Brnabic as Serbian $\mathrm{PM}$ and the discourses surrounding it in an EU-oriented Serbia should be addressed by taking into account the broad conceptual link between issues of sexuality and geopolitics (Brković 2014), and specifically by considering the "symbolic nexus" between "Europeanisation" and "gay emancipation" (Bilić and Stubbs 2016). A number of scholars have noted that the biggest impetus for the redefinition of sexual politics in the Central and Eastern European (CEE) and West Balkan countries has been the EU accession process (Kahlina 2013; Butterfield 2013; Kahlina 2014; Kulpa 2014; Brković 2014; Bilić and Stubbs 2016, etc.). Such scholars have considered key concepts including homonationalism, leveraged pedagogy, and sexual citizenship to examine the entanglement of sexual rights and EU accession processes. These concepts help to illuminate an overarching Orientalist discourse that authorizes a disciplining pedagogical treatment of postcommunist countries by the EU - on the grounds of their lack of respect for sexual rights - by engendering hierarchical and nesting binaries between the EU 15 and the CEE and Western Balkan Countries.

In this essay, I examine how a "leveraged pedagogy" centring on sexual minority rights has been performed and negotiated in Serbia and 
how the appointment of a lesbian Prime Minister can be interpreted in this conceptual framework. First, I address the dynamic interrelation between the concepts of leveraged pedagogy, homonationalism and sexual citizenship to highlight the workings of the disciplining discourses of the EU. In particular, I examine discourses of Europeanisation that translate the genuine respect of tolerance and inclusivity into a performative act of adherence to hegemonic constructions of European identity. Second, I closely analyse selected statements issued by President Vučić and his successor and mentee Ana Brnabić. I focus on the mechanism by which the political agency of a gay Prime Minister is disempowered and subdued, drawing on Foucault's classic thesis that the disciplinary effects of discourse produce "docile bodies" that may be "subjected, used, improved and transformed" (Foucault 1979; also cited in Barker 2005: 230). I highlight structural parallels between the disciplinary mechanisms that characterize both wider discourses of Europeanisation and the rhetoric of pro-European political elites in Serbia. My central argument is that the "morphosyntactic" parallels between the two discourses coalesce into a common language of discipline that produces an alternative subject position in power whose agency is essentially cancelled.

In conclusion, I propose that the similarities between the disciplining regimes of the two discourses could be understood in terms of a "nesting pedagogy." "Nesting pedagogy" is a terminological and conceptual hybridization of "nesting Orientalism" (Bakić-Hayden 1995) and "leveraged pedagogy" (Kulpa 2014); for the purposes of this essay, I use it to denote disciplinary regimes emanating from the EU which, as they cascade south-eastwards toward the bloc's periphery, produce nested hierarchical binaries marked by the pedagogic and infantilizing treatment of the Other. Throughout my discourse analysis of statements by Vučić and Brnabić, I bear in mind that discourse is not accidental and neutral, but rather a "place where sexuality and politics exercise some of their most formidable powers" (Foucault 1981:53).

\section{Sexual citizenship and European identity}

The process of EU accession has come to be characterized by the pressures of conditionality, marked by the "moving target problem", whereby EU requirements may be continually redefined in a game in which the European 
Andrijana Aničić: The Common Language of Discipline

Union "is a referee as well as a player" (Grabbe 2002: 251; also cited in Butterfield 2013: 17). Kulpa, for example, argues that the interaction between CEE and West European countries is couched in a "didactical and cultural hegemonic relationship of power" (Kulpa 2014: 432). He defines this power asymmetry as leveraged pedagogy, "a discourse of unequally distributed power between the one that supposedly knows better, and assumes itself in the teaching and dominant position (West/Europe), and the one who is discursively overpowered, and is framed as backward, thus in need of being educated up (CEE) by the former" (Kulpa 2014: 441). Underlying leveraged pedagogy is a concept that illuminates the historical shift by which dominant heteronormative paradigms of the nation state have begun to integrate homonormativity and tolerance of gay citizens as a litmus test of national integrity and development (Puar 2007; Puar 2013). Puar has introduced the term homonationalism to account for the West's ideology of superiority as measured by their inclusivity of gay subjects and, crucially, as measured against states framed as the homophobic Other. In the European context homonationalism is understood as a discursive tool for "othering" peripheral countries that struggle to prove their progress by improving the citizenship status of sexual minorities.

The concept of sexual citizenship could be broadly defined as "membership in a particular polity that has been established on the grounds of sexuality" (Kahlina 2013: 2).The last two decades have seen significant changes in the politics of sexuality in Western liberal democracies as evidenced inthe increasing emphasis on issues of sexual and intimate citizenship. Discourses of tolerance and respect for social diversity have ushered in the perception of lesbian and gay people as "normal good citizens who are deserving of inclusion and integration into the mainstream society" and the nation state (Richardson 2004: 392). The emerging notion of sexual citizenship has revealed patterns of exclusion by pointing to the limited scope of rights granted to sexual minorities across societies. In the post-Yugoslav countries, decriminalisation of minority sexual practices took place at different times. The socialist federal republics of Slovenia, Croatia, and Montenegro decriminalised homosexuality in 1977, whereas in Serbia decriminalisation took place in 1994. Decriminalisation, however, did not result in equal citizenship status for sexual minorities because they were not granted a wide range of rights guaranteed to heterosexual families, such as next-of-kin inheritance and unemployment and pension rights, recognition for immigration purposes, the right to visit partners in 
hospital, etc. (Richardson 2004, Kahlina 2013, ILGA-Europe 2016). In exYugoslav countries, the equal citizenship status of sexual minorities is still a matter of struggle and negotiation, with Slovenia and Croatia reaching the highest standards by passing the Same-Sex Partnership Act. ${ }^{3}$

Although the struggle over sexual citizenship has facilitated positive global changes in sexual politics by reshaping public debate and legal frameworks, a number of authors have argued that it has also generated further geo-political cleavages and exclusions (Kahlina 2012; Butterfield 2013; Kahlina 2013; Colpani and Habed 2014; Kahlina 2014). Moreover, LGBT civil rights have provided a broad arena for the struggle over EU enlargement and Europeanisation, national identity and modernity (Kahlina 2014: 2). The discourses that have emerged from these struggles focus on the articulation and appropriation of ideologically laden concepts of European identity, European values and human rights. Butterfield (2013), for example, argues that sexual rights have become an effective tool in the discursive construction of European identity and the definition of proper Europeanness. In her view, the discursive construction of European identity through sexual rights has had the effect of redefining the borders of Europe. By re-inscribing Orientalist binaries, discourses of sexual citizenship have sharply distinguished developed West European societies from backward, homophobic East European cultures: "permanently 'post-communist', 'in transition' and 'not liberal enough"' (Kulpa 2014: 432).

Butterfield (2013) also emphasizes that the increasing centrality of "human rights" ideology to the construction of European identity coincided meaningfully with the collapse of socialist regimes across Eastern Europe and the former Soviet Union - and with the turbulent processes of "transition" in the region that ensued. Indeed, when the Copenhagen Criteria, the basic requirements for the integration of post-socialist countries into the $\mathrm{EU}$, were set just after the fall of the Iron Curtain in 1993, human rights issues began to play a central role in the effort to distinguish those countries that were ready or unready for membership. In this way, "the EU has positioned itself as the gatekeeper of human rights" (Butterfield 2013: 16): it set for itself the power to define what these rights might be and to evaluate the moral-political progress of entire nations accordingly.

3 Croatia's parliament endorsed the Life Partnership Act in 2014. This act grants samesex couples rights equal to those guaranteed to married couples, with the exception of adoption rights. 
The field of human rights as a source of civilizational standards has only recently expanded to include sexual rights (Stychin 2004: 953). Prior to the 2000s, the protection of sexual rights had not been a requirement for EU accession. After the turn of the millennium it gradually became a barometer of social equality in the EU, thus rendering provisions against discrimination in the workplace and decriminalisation of homosexuality "explicit requirements for EU accession in 2004 and 2007" (Kahlina 2014: 3 ), when European countries of the former Soviet Bloc joined the union. However, even stronger emphasis on the treatment of sexual minorities was noted when the post-conflict societies of Serbia and Croatia applied for membership, in 2003 and 2009 respectively. This is when "LGBT rights became part of the 'leveraged pedagogy' of the EU" (Kahlina 2014: 2) and one of its most plastic applications of discipline. The monitoring process of EU institutions in Serbia and Croatia focused particularly on two key points, the adoption of anti-discrimination legislation and the organisation of state-protected Pride Marches (Kahlina 2013; Kahlina 2014).

In 2009, a draft Anti-Discrimination Act that included provisions prohibiting discrimination based on gender and sexual orientation was presented in the Serbian Parliament, but was immediately removed from the legislative procedure as it encountered serious opposition from the Orthodox Church. A vocal opponent of such a provision was the current President, Aleksandar Vučić, then an opposition MP, who feared the protection of minority sexual practices would take Serbia down a slippery slope to the protection of "sodomy and paedophilia" (Stakić 2011: 53). However, after the withdrawal of the Act was met with harsh criticism from European institutions ${ }^{4}$ and additionally presented as a "direct condition for lifting the visa requirements" (Kahlina 2014: 5), the Act was returned to Parliament and adopted with some amendments.

The cancellation of the 2009 Pride March due to threats of violence again sparked criticism from EU officials, which as a powerful corrective factor "consequently led to a shift in the discourse of the Serbian political elite regarding the Parade" (Stakić 2011: 54). As Stakić notes, the biggest opposition party at that time, the SNS, changed its stance on LGBT issues and Aleksandar Vučić condemned violence and discrimination against sexual minorities when the first successful Belgrade Pride March took place in 2010. The significance of the Pride March in the EU monitoring

4 The Swedish Helsinki Committee for Human Rights termed this law a "civilisation achievement" (B92 2009). 
process and for Serbia's prospective candidacy was highlighted by the presence of the head of the EU mission in Serbia, Vincent Degert. Degert directly addressed the marchers, fortifying them to persist in their struggle for tolerance, freedom of expression and freedom of assembly (BBC 2010). Violent clashes with ultranationalists and hooligans that erupted during the March subsequently led to a three-year ban on the event being organised.

In response to yet another failure by Serbia to fulfil the requirements regarding the organisation of the Pride March in 2012, EU officials applied additional leverage by drawing on conditions for the commencement of accession negotiations. Reacting to the Serbian government's apparent fearfulness and inability to safeguard the Pride March from potential threats by hooligans, Dutch MEP and a member of the Committee on Women's Rights and Gender Equality, Marije Cornelissen, said that she was going to "recommend to the Commission that they should not allow for accession talks to begin" (Hall 2012). The organisation of Pride Marches in Belgrade resumed in 2014 - when Aleksandar Vučić became Serbia's Prime Minister, the most power he had had in his career up to then.

As we have seen in the examples above, resistance to or lack of compliance with EU standards for sexual citizenship on the part of the Serbian political elites is met with criticism and condemnation from EU officials and direct conditioning connected to the accession process and to benefits that are strategically granted or withdrawn in the course of negotiations. These examples also reveal how Serbian politics is reshaped and swiftly adapted in accordance with EU demands, and how leading political figures readily yet suspiciously redefine their stances with respect to sexual rights when the main political aim of joining the EU becomes jeopardised. The "whip and carrot" model, as Kulpa (2014) characterises leveraged pedagogy, seems to focus exclusively on the results expected to be delivered (or performed), disregarding the questionable sincerity of Serbian pro-European politicians' sudden embrace of equal rights. Regardless of actual improvements in everyday conditions for sexual minorities, the negotiation process is shaped by a relationship of power asymmetry, in which Balkan politicians respond to the EU's disciplinary pedagogy and the expected commitment to European values with performances of European identity. Moreover, by framing the fulfilment of EU conditions as a continual progression towards European values and civilisational standards, the EU engages in a discursive construction of the Western Balkan countries as permanently in transition and in need of guidance and surveillance. 
Buden (2010) recognises this pedagogical treatment in the discursive strategies deployed by the democratic West that frame post-communist countries as politically immature children in a perpetual post-communist state. Although these societies might be understood to have proved their maturity by toppling totalitarian regimes, they need to be continually educated in "classrooms of democracy" and prove their progress in "democratic exams" (Buden 2010). Buden argues that the "jargon of postcommunist transition" is permeated with child metaphors that are indicative of a "new power relationship" exhibiting a "repressive infantilisation" of these societies (Buden 2010).

In the discussion above we have seen how European values and sexual citizenship have increasingly become discursive instruments for homonationalist practices of dividing European space into the properly European and the homophobic Other whose European identity is yet to be attained. ${ }^{5}$ The discursive deployment of unequal sexual citizenship engenders further geopolitical ideological binaries not only between the EU and post-Yugoslav space, but also within the former Yugoslavia (Bilić 2016). In a panoramic worldview of nesting Orientalisms, the border between the civilized/tolerant and uncivilized/homophobic space seems to cascade from the West eastwards, engendering further hierarchical divisions on an ever diminishing scale. Thus, on the "imaginary sliding scale of the nesting Balkans", Slovenia and Serbia occupy the extreme ends of the spectrum, both in terms of their status when it comes to EU membership and their tolerance for minority sexualities (Moss 2014: 219). On a smaller scale, the workings of the nesting Balkans have drawn a distinction between the elite "liberal intellectuals and activists" who are "emphasizing the backwardness of the region in the relation to an imagined West" (Bilić 2013: 136, as cited in Bilić and Stubbs 2016: 234) and their homophobic Other, who finds it their patriotic duty to denounce gay rights "as the epitome of the 'Western values' that threaten 'the authentic Serbian tradition and Serbian society"' (Kahlina 2013: 20). For both of these groups the tolerance of non-heterosexual practices has been seen as emanating from European identity; thus, they both use sexual citizenship (albeit at opposite ends of the binary) as a discursive instrument in architecting their

The trouble with such hierarchical binaries is that they are inevitably premised on homogeneously constructed fixed identities that contradict (political) realities, for as Freire notes in the Pedagogy of the Oppressed, "reality is a process undergoing constant transformation" (Freire 2000: 75). 
Other, as well as their own identitarian premises. In their pro-European strategies, Serbian political elites are compelled to bear this in mind and balance their statements, both respecting the sensibility of their electorate and discursively moulding it.

\subsection{Please allow me to introduce Ana}

In August 2016, Prime Minister Aleksandar Vučić nominated Ana Brnabić for the position of Minister of Public Administration and Local SelfGovernment. Brnabić, a technocrat with an enviable business career, was plucked from relative political obscurity as she was not a member of any political party. As a local director of the American corporation Continental Winds Serbia, she was implicated in a scandal in which Vučić's brother and a close friend were accused of blackmailing the company. By testifying that the company had not been blackmailed, she resolved the scandal, and according to popular belief in Serbia (Gligorijević 2017; Drčelić 2017), was rewarded for her cooperation by becoming a Serbian minister in Vučić's government. To dispel potential suspicion as to the moral legitimacy of an official state promotion of a person who under unclear circumstances had bailed out the Prime Minister's close friends and family, Vučić rushed to announce that the Serbian Government would appoint an openly lesbian minister. In this way, at a single stroke, Vučić deflected attention away from the scandal by spotlighting Brnabićs sexual orientation rather than her credibility - and, more importantly, portrayed himself as a progressive leader committed to European values of tolerance and inclusivity.

In announcing his new cabinet, PM Vučić addressed the National Assembly as follows:

The Government of Serbia will have a Minister who publicly declares herself as a person of homosexual orientation. Ana Brnabić, who will be the Minister for State Administration and Local Self-Government, is a member of the gay population. She doesn't hide it and proudly talks about it. She is so sweet and kind, she told me: 'President, I hope you don't mind, I am certain that this will be a topic for them...' And I replied: 'No, all that is of interest to me is your results, and I know how hard-working and 
dedicated you are.' I don't care, it's her right, I am only interested in her results. ${ }^{6}$

In Serbia, the politics of gay visibility is countered with "stigmatising discourses of "privatisation", in which the ostensible tolerance of homosexual individuals is conditioned upon their remaining "in the closet" (Kahlina 2014: 5). In his statement, Prime Minister Vučić pointedly endeavours to dismantle the public/private binary by publicly outing Minister Brnabić and emphasising her sexual identity twice. By using the word "proudly," evocative of the Pride Marches, it is as if he is staging a discursive mini-march with Minister Brnabić parading in the Parliament freely expressing her sexuality. However, this image is far from plausible, for it is through the Prime Minister's words and not from Brnabic that we learn about her pride.She has no agency in this introduction or in her outing by her superior. It appears that Brnabić's sexuality is her most important qualification for the ministerial appointment, since the Prime Minister discloses this aspect of her identity even before mentioning her name. Still, vigilantly keeping in mind that a large part of his electorate would be disturbed by this measure, in a reassuring gesture the Prime Minister describes Brnabić as "sweet and kind," thus re-gendering her by invoking a traditional image of femininity. Through the reported alleged dialogue we also learn that Ana Brnabić is apologetic about her sexuality and insecure, expecting condemnation and disapproval. Again the Prime Minister appears as both a firm and reassuring paternal figure, promising redemption and protection conditioned on the results he expects to be delivered. First, Ana is outed, then re-gendered, and finally presented as a dedicated professional, all to prepare the general public to eventually accept her as their new minister. She is first publicly inspected as a suspicious subject, then neutralised and disarmed, and finally accepted as a valuable staff. What is being signalled in this way is that that Brnabic can be trusted to usher in the transformation of sexual citizenship in Serbia - and even the cultural transformation of Serbian society at large - without seriously

6 "Vlada Srbija imaće i jednu ministarku koja se javno izjašnjava kao osoba homoseksulane orjentacije. Ana Brnabić, koja će biti ministarka države uprave i lokalne samouprave pripadnik je gej populacije. Ona to ne krije i sa ponosom govori. Ona je toliko fina i ljupka, rekla mi je: Predsedniče, ako vam to smeta, sigurna sam da će o tome sada da govore... a ja sam odgovorio: Ne, mene zanima samo tvoj rezultat, a znam koliko si stručna i vredna. Baš me briga, to je njeno pravo, mene zanima njen rezultat." (Blic online 2016) 
threatening traditional gender norms or the prejudices of many Serbian constituencies.

The next set of intriguing statements came a year later, following the parliamentary session in which the National Assembly endorsed President Vučić's proposal that Ana Brnabić be appointed Prime Minister. Although his ruling party with its coalition partners held an overwhelming majority of seats in the Parliament and the ratification of the President's decision was never in doubt, several days before the decisive session Vučič and his party comrades raised suspicions as to the Parliament's willingness to give their support to Ana Brnabić. Sensationalist news headlines such as "Tempest in SNS", "Big drama over appointment of Ana Brnabić" and "Vučić appeals to MPs to lend their support to Ana Brnabić" indicated that the stability of the state was at stake since the deadline for the appointment of a new government was approaching and traditional opponents of sexual rights ${ }^{7}$ were voicing their opposition to the election of a gay Prime Minister. Tensions were further raised in the print media that featured photographs from parliamentary sessions in which Ana Brnabić was clasping her hands in suspense. Nevertheless, as was to be expected despite the voices of those who opposed Brnabić, the parliamentary majority for Brnabićselection was easily secured.

Once Serbia had its new Prime Minister, President Vučić gave an interview on state television. Explaining the difficulties and fears he had faced along the way, he said: "[the appointment of Brnabić] was my wish, but I didn't know if I would have the strength to propose it, let alone if the proposition would be passed", and also "I was faced with various kinds of pressure, but it's no use whining about it now". ${ }^{9}$ He also said that there were three people in his party who were against the proposition and added:

I understood their fears for my standing in the opinion polls. A very nice man who has family in the clergy said that it was hard for him to accept, I asked him nicely, and then he said that he would vote in favour and he would do it for me. Ana is a good

7 The Orthodox Church, opposition parties such as the Serbian Radical Party led by Vojislav Šešelj, together with United Serbia - a minor party led by Dragan Marković Palma forming the ruling coalition with the SNS.

8 "To je i tada bila moja želja ali nisam znao da li ću imati snage da to predložim, a kamoli da li će to da prođe."(B92 2017b)

9 “Bio sam sa različitim vrstama pritisaka suočen, ali što sad da kukam?” (RTS 2017) 
creature, a good person, somebody who knows how governance functions... Ana is a capable and hardworking woman. ...I told Palma that I disagree with him. Palma acted very correctly towards the government of Serbia and I hope that he will change his stance. I beseech him to change his stance. I can understand, Rističević10 $^{10}$ told me that he would never be in favour of the gay parade. And I told him that he would never see me there either, that it is not my world, but it has to be allowed. How can we obstruct people who want to show themselves at a gathering organised in accordance with the law ${ }^{11}$

Building on Buden's point evoking Hegel's equation of "nonaction" and innocence (Buden 2010), I suggest that presenting a person as innocent is a discursive method of depriving them of the capacity to be perceived as a mature, autonomous subject, thus erasing their agency. Ana is "desubjectivated" (Buden 2010) and neutralised by being defined as a "good creature," then re-humanised as a "good person", and finally restored to her public function as a high-performing technocrat. Again, the acknowledgement of what she "really" is - a woman - is conditioned upon her hard work and compliance, and the final destination of this discursive identity transformation that she undergoes is the delivery of (unspecified) results.

President Vučić has built a heroic narrative, of which he himself is the protagonist. He is faced with a difficult challenge and so seeks moral guidance from reputable people related to the clergy. While respecting their cultural authority, it is through his powerful charisma that he manages to subordinate their traditional values to the higher interests of Serbia: advancement towards the EU and respect for European norms. Gay pride is not his world, but that world "has to be allowed." This discursive technique pertains to what Kahlina (2014) argues is a common strategy of

10 Opponent of Brnabić's appointment and Vučić's coalition partner.

11 "Razumeo sam njihovu bojazan za moj rejting. Jedan divan čovek koji potiče iz svešteničke porodice je rekao da je to za njega teško, ja sam ga onda zamolio, a on je rekao da će zbog mene glasati za. Ana je dobro stvorenje, dobar čovek, neko ko zna kako stvari u upravi funkcionišu. Ana je sposobna i vredna žena", "Rekao sam ja Palmi da se ne slažem s njim. Palma je bio veoma korektan u odnosu prema Vladi Srbije, ja se nadam da će on svoj stav da promeni. Ja ga molim da svoj stav promeni. Ja mogu da razumem, Rističević mi je rekao da nikada neće biti za gej paradu, rekao sam mu da ni mene neće naći tamo, da to nije moj svet, ali da to mora da se dozvoli. Kako da ne pustimo ljude koji hoće u skladu sa zakonom organizovanim skupom da pokažu sebe?" (B92 2017b) 
pro-European elites in the Western Balkans: externalising the imperative for equal sexual rights by attributing it to EU conditionality, while at the same time preserving their image as grudging yet noble protectors of the very same rights and subjects. Interestingly, this moment of Vučić's discourse resembles the protracted silence described at the beginning of this paper and the discreet signals exchanged between members of the SNS when faced with the necessity to refrain from outspoken homophobia in Parliament. Whether using gestures in non-verbal communication in Parliament or modal constructions that externalise the responsibility for unpopular measures, the pragmatics of their discourse reveals that political actors presuppose the common awareness of the necessity to collaborate in performing acts of tolerance for homosexuality.

Reaching for one of his favourite narrative devices, the President opts for a dialogue with imaginary interlocutors who epitomise particular ideological positions. This narrative device signals that we are in the realms of strategic storytelling, which functions to instruct the nation on how to perceive and react to their new political-sexual reality. In a sweeping nesting pedagogy aimed at the Serbian electorate at large, President Vučić devises dialogic parables that discipline and infantilise both his new Prime Minister and the population she will - at least in name - govern.

\subsection{Can the subaltern speak?}

In an interview given to CNN in July 2017, responding to questions on how her appointment has been received in a deeply conservative Serbian society, Ana Brnabić says that she has never experienced any discrimination in Serbia and she believes that Serbia is not homophobic or xenophobic, but rather is only perceived as such due to the actions of a "loud minority" (CNN 2017).

In another interview with the Guardian (Wintour 2017), Brnabic reiterates that Serbia is not a homophobic society, but rather a society which is changing quickly, with her being part of that change. She also shares an illustrative anecdote in which a group of journalists interviewed local people from the village Ana's family comes from. She alleges that they said: "Well, listen, in this part of Serbia we grow raspberries, fruit and vegetables, and we do not grow discrimination."

The fact that Brnabić has never experienced discrimination in Serbia is a valuable optimistic insight, albeit entirely contrary to reports made 
by international organisations whose statistical data has shown that the discrimination and stigmatisation of non-heterosexual citizens is part of their day-to-day reality in Serbia (ILGA-Europe 2016; 2017). ${ }^{12}$ Thus, as a representative of a minority group, the Prime Minister seems to show a surprising level of tolerance for Serbia's starkly unequal sexual citizenship.

In tune with Vučić's 2017 SNS presidential campaign slogan "Faster, stronger, better" and his government's optimistic reports that continuously record economic and political improvements in Serbia, Brnabić claims that her appointment demonstrates the progressive changes taking place. However, she not only fails to acknowledge the lived experience of marginalisation faced by sexual minorities, but in fact openly denies this experience, and reiterates the discourse of linear progress. She declares that President Vučić should mentor her work in the first few months (Danas 2017) and, mirroring her mentor's didactic techniques, engages in a dialogue with ideological positions that might be suspicious of this pattern of progress. Her dialogic parable seems to instruct farmers that they too should be focused on productivity and delivering results, not discrimination.

Drawing on the work of Katja Kahlina $(2013 ;$ 2014), in the discussion above I have noted the privileged role that the notion of Gay Pride has assumed in the EU's "leveraged pedagogy". One visible change that did take place upon Brnabićs appointment was her support of and participation in the Pride March in September 2017, whereupon she became the highest ranking Serbian official to make an appearance at the parade. Keeping his word, President Vučić did not participate in the parade, but since "it has to be allowed" - the source of the obligation coming from the outside - his protégé Brnabić did, thus sending a (rather un-)clear message of the Serbian government's commitment to European values concerning the freedom of assembly for sexual minorities.

In one of several recent scandals to shake the media scene in Serbia, an investigative journalism portal revealed that a member of Brnabićs cabinet, the Minister of Defence, who in the 1990s was a close political

12 It is important to note that this paper does not aim to question findings of international organisations involved in the monitoring process of the EU. It is beyond doubt that their insights are valuable indicators of everyday inequalities experienced by people in SouthWestern Balkan. The broader discourse in which the monitoring process is implicated, however, remains problematic and subject to analysis. 
associate of Slobodan Milošević, had acquired a suspiciously large sum of money that he had not reported to the tax agency. In response to these serious accusations the Defence Minister and his party, the Movement of Socialists, subsequently deployed rhetoric typical of Milošević's era, riven with hate speech and abusive labels centring on the "dichotomy into patriots vs. traitors" (Bugarski 2001: 76). The journalist leading the investigation was exposed to public stigmatisation and accused of being a foreign agent and a drug addict (Pokret socijalista Aleksandar Vulin 2017). Commenting on the affair, Brnabic dismissed the gravity of what seemed to constitute a clear case of the intimidation of journalists, claiming that it was an understandable emotional reaction on the part of the Minister's party. Furthermore, it seems that, contrary to the findings of the European Federation of Journalists (EFJ 2017) and the Reporters without Borders ${ }^{13}$, as well as mounting complaints by Serbian journalists that they face constant pressure and threats, Brnabic thinks that the only problem with the media scene in Serbia is that journalists are not objective enough (Fondacija Slavko Ćuruvija 2017).

In her public statements, Brnabić has shown considerable tolerance for the unequal citizenship of sexual minorities, indications of corruption, hate speech, and intimidation of the press, while at the same time positioning herself as indisputable evidence of the progress that Serbia has made in the EU accession process. Her ambiguous position can be understood through the Gramscian model of hegemonic power, in which hegemony is predicated on subordination effected not only through coercion, but, crucially, through consent (Barker 2001). Brnabić's statements reveal her consensual acceptance and identification with the subject position carved out for her by hegemonic disciplinary mechanisms. By reproducing the same disciplinary strategies as her patrons, Brnabić, as a member of a marginalised community, seems to allow "its own marginality to be upheld" (Bogetić 2010: 37). Moreover, she has demonstrated that tolerance of inequality and official commitment to European values as measured by the EU do not appear to be mutually exclusive.

13 According to Reporters without Borders' report: "Media freedom has declined ever since Aleksandar Vucic, Slobodan Milosevic's former information minister, became Prime Minister in May 2014. The media work under harsh financial and editorial pressure, and those that are most critical of the government are attacked publicly." Available at: https://rsf.org/en/serbia 


\section{Conclusion}

In this paper, I have focused on how discourses of European values and human rights, which have in the past two decades expanded to include sexual rights, have helped to construct and sustain geopolitical divisions that reproduce much older Orientalist hierarchies and ideologies.

These homonationalist discourses have rendered EU accession processes a disciplinary technology aimed at the improvement of democratic standards in candidate countries, primarily the post-socialist states of East Europe. Such disciplinary regimes can be understood as leveraged pedagogies in which the EU is framed as the protector of civilisational standards and social equality, thereby authorizing didactical techniques of conditioning, criticising, educating and infantilising.

Meanwhile, in EU-aspiring Serbia political actors have appropriated a similar set of disciplinary discourses. As President Vučić's public statements reveal, he posits himself as a heroic paternal figure protecting both the traditional values and concerns of Serbia and European values, devising narrative strategies in his discourse that educate, instruct, discipline and finally infantilise his audience and electorate.

I propose the term "nesting pedagogy" to account for the process by which the disciplinary regimes of the EU travel eastward and become appropriated by the pro-European political elites whose commitment to European values is largely performative. In a sweeping cascading motion, European nesting pedagogies grounded in the citizenship status of sexual minorities generate geographical hierarchical binaries between civilized and less civilized spaces. As the cascade reaches the Western Balkans and Serbia, in a sequence of repeated reflections these divisions set the boundary between progressive intellectuals and their homophobic, traditionalist Other. Finally, this kaleidoscopic moving perspective of ever smaller dichotomies lands on the homosexual citizen, in this case the final object of nested othering.

Attending to such nesting pedagogies helps to illuminate the significance of the appointment of a lesbian Prime Minister in Serbia. Her statements in the analysis above suggest complete subordination and the fact that, as an alternative subject in power, she is given only enough political legitimacy to perpetuate the dominant discourses of progress. My argument is that nesting pedagogy has enabled a powerful idiom of discipline used by EU and Serbian political elites alike, whose main purpose 
is to elicit the performance of European identity without fully compelling its adoption. It is in this way that the common language of discipline has created a disciplined and "disciplinary gay liberal subject able to perform Europeanness" (Colpani and Habed 2014: 83).

In conclusion, I would like to build on the optimistic trope from the introduction of this paper, by supplementing it with an image from T. S. Elliot's Waste Land (Eliot 1999): if Brnabić's becoming Prime Minister of Serbia made the glass ceiling break, it did not break with a bang, but rather - with a whimper.

\section{References}

Bakić-Hayden, M. (1995). Nesting Orientalisms: The Case of Former Yugoslavia. Slavic Review, 54.4, 917-931.

Barker, C. (2005). Cultural Studies, Theory and Practice. London, Thousand Oaks, New Delhi: Sage Publications.

Bilić,B. (2016).Europeanisation,LGBTActivism, andNon-Heteronormativity in the Post-Yugoslav Space: An Introduction. In: B. Bilić (ed.), LGBT Activism and Europeanisation in Post-Yugoslav Space: On the Rainbow Way to Europe, UK: Palgrave Macmillan, 1-22.

Bilić, B and P. Stubbs. (2016). Beyond EUtopian Promises and Disillusions: A Conclusion. In: B. Bilić (ed.), LGBT Activism and Europeanisation in Post-Yugoslav Space: On the Rainbow Way to Europe, UK: Palgrave Macmillan, 231-248.

Bogetić, K. (2010). As Long as You're not Effeminate and Fat: Perpetuating the Heteronormative Discourse in Personal Ads of Serbian Gay Youth on the Web. Proceedings of the Annual Meeting of the Berkeley Linguistics Society, Vol. 35, 37-48.

Brković, C. (2014). The Quest for Legitimacy: Discussing Language and Sexuality in Montenegro. In: Mirroring Europe: Ideas of Europe and Europeanization in Balkan societies.Tanja Petrović (ed.), Leiden, The Netherlands: Brill, 163-185.

Buden, B. (2010). Children of Postcommunism. Radical Philosophy, 159. http://www.identitymove.eu/assets/pdf/boris\%20buden.pdf (accessed 1 November 2017)

Bugarski, R. (2001). Language, Nationalism and War in Yugoslavia. International Journal of the Sociology of Language, 151, 69-87. 
Butterfield, N. (2013). Sexual Rights as a Tool for Mapping Europe: Discourses of Human Rights and European Identity in Activists' Struggles in Croatia". In: A. P. Balogh and N. Frejes (eds.), Queer Visibility in PostSocialist Cultures, Bristol and Chicago: Intellect.

Colpani, A. and A. J. Habed. (2014). "In Europe It's Different": Homonationalism and Peripheral Desires for Europe. In: P. M. Ayoub and David Paternotte (eds.), LGBT activism and the making of Europe: A rainbow Europe, London: Palgrave Macmillan, 73-93.

Eliot, T. S. (1999). The Waste Land and Other Poems. London: Faber and Faber.

Foucault, M. (1979). Discipline and Punish. New York: A Division of Random House, Inc.

Foucault, M. (1981). The Order of Discourse. In: R. Young (ed.), Untying the Text: A Post-Structuralist Reade, Boston, London and Hanley: Rutledge and Kegan Paul, 51-79

Freire, P. (2000). Pedagogy of the Oppressed. London: Continuum.

Grabbe, H. (2002). European Union Conditionality and the Acquis Communautaire. International Political Science Review, 23.3, 249-268.

ILGA-Europe. (2016). ILGA-Europe's Submissions to Progress Report of European Commission: Update of Submission, August 2016. https:// www.ilga-europe.org/sites/default/files/enlargement_review_serbia_ 2016.pdf (accessed 15 November 2017)

ILGA-Europe. (2017). ILGA-Europe's Submissions to Progress Report of European Commission: Overall Enlargement Review 2017. https:// www.ilga-europe.org/sites/default/files/annual_lgbti_enlargement_ review_2017_ilga_europe.pdf (accessed 20 November 2017)

Juras, S. (2009). 2009 Annual Report on the Status of Human rights of Sexual and Gender Minorities in Croatia. Kontra, Zagreb.

Kahlina, K. (2012). What's Sexuality Got to Do With it? On Sexual Citizenship. CITSEE stories. http://www.citsee.eu/citsee-story/ what $\%$ E2\%80\%99s-sexuality-got-do-it-sexual-citizenship(accessed 26 October 2017)

Kahlina, K. (2013). Contested Terrain of Sexual Citizenship: EU Accession and the Changing Position of Sexual Minorities in the Post-Yugoslav Context. CITSEE Working Paper Series 2013/33.

Kahlina, K. (2014). Local Histories, European LGBT Designs: Sexual Citizenship, Nationalism, and "Europeanisation" in Post-Yugoslav 
Croatia and Serbia. Women's Studies International Forum. http://dx.doi. org/10.1016/j.wsif.2014.07.006 (accessed 3 October 2017)

Kulpa, R. (2014). Western Leveraged Pedagogy of Central and Eastern Europe: Discourses of Homophobia, Tolerance and Nationhood. Gender, Place and Culture: A Journal of Feminist Geography, 21, 431-448.

Moss, K. (2014). Split Europe: Homonationalism and Homophobia in Croatia. In: P. M. Ayoub and David Paternotte (eds.), LGBT Activism and the Making of Europe: A Rainbow Europe. London: Palgrave Macmillan, 212-232.

Puar, J. (2007). Terrorist Assemblages: Homonationalism in Queer Times. Durham, NC: Duke University Press.

Puar, J. (2013). Homonationalism as Assemblage: Viral Travels, Affective Sexualities. Jindal Global Law Review, 4.2, 23-43.

Richardson, D. (2004). Locating Sexualities: From Here to Normality. Sexualities, 7.4, 391-411.

Stakić, I. (2011). Homophobia and Hate Speech in Serbian Public Discourse: New Nationalist Myths and Stereotypes Influence Prejudices against the LGBT Minority. The Equal Rights Review, 7, 44-65.

Stychin, C. (2004). Same-Sex Sexualities and the Globalisation of Human Rights Discourse. McGill Law Journal, 49, 951-968.

\section{Online media sources}

B92 (2009). Zakonom protiv diskriminacije [Fighting discrimination with law].B92.net. https://www.b92.net/info/vesti/index.php?yyyy=2009 $\& m m=02 \& d d=24 \& n a v \_i d=346801$ (accessed 4 October 2017)

B92 (2017a). Ko je protiv Ane, taj je protiv Vučića-isključenje [Those against Ana are against Vučić - expulsion]. B92.net https://www. b92.net/info/vesti/index.php?yyyy $=2017 \& \mathrm{~mm}=06 \& \mathrm{dd}=19 \&$ nav category $=11 \&$ nav_id $=1273727$ (accessed 17 October 2017)

B92 (2017b). Želja mi je bila da predložim Brnabić, plašio sam se SNS [It was my wish to nominateBrnabić, I feared the SNS]. B92. https:// www.b92.net/info/vesti/index.php? yyyy $=2017 \& \mathrm{~mm}=06 \& \mathrm{dd}=20 \& \mathrm{n}$ av_category $=11 \&$ nav_id $=1274236$ (accessed 26 September 2017)

BBC (2010). Scores arrested in Belgrade after anti-gay riot. BBC online. http://www.bbc.com/news/world-europe-11507253 (accessed 11 November 2017) 
Blic online (2016). Gejministarka u Vladi [Gay minister in Government]. Blic online. http://www.blic.rs/vesti/politika/vucic-gej-ministarka-uvladi/8lfqn53(accessed 25 September 2017)

CNN (2017). Serbia's first female openly gay PM on her new role. Amanpour. https://edition.cnn.com/videos/world/2017/07/19/intv-amanpourana-brnabic-serbia.cnn (accessed 1 November)

Da se zna (2017). Šta izbor Ane Brnabić za premijerku Srbije (ne) znači za LGBT zajednicu u Srbiji [What does the appointment of Ana Brnabicas Serbian Prime Minister (not) mean for the LGBT community in Serbia]. Peščanik. http://pescanik.net/sta-izbor-ane-brnabic-za-premijerku-srbijene-znaci-za-lgbt-zajednicu-u-srbiji/ (accessed 29 September 2017)

Danas (2017). Vučić da ima ulogu mentora nad premijerom [Vučić should be Prime Minister's mentor]. Danas. http://www.danas.rs/politika.56. html? news_id $=347800 \&$ title $=$ Brnabi $\% C 4 \% 87 \% 3 \mathrm{~A}+\mathrm{Vu} \% \mathrm{C} 4 \% 8 \mathrm{Di} \%$ $\mathrm{C} 4 \% 87+\mathrm{da}+\mathrm{ima}+\mathrm{ulogu}+$ mentora + nad + premijerom(accessed $\quad 15$ November 2017)

Dinić, R. (2017). Marionetsko pozorište [Marionette theatre]. Peščanik.http:// pescanik.net/marionetsko-pozoriste (accessed 6 November 2017)

Drčelić, Z. (2017). Najnovija vlada Aleksandra Vučića: Ana, Palma i kum Siniša Mali [Vučić's brand new government: Ana, Palma and godfather Siniša Mali]. Vreme. http://www.vreme.com/cms/view. php?id =1509814\&print=yes (accessed 9 November 2017)

EFJ (2017). Serbia: Attacks against journalists must stop. European Federation ofJournalists.https://europeanjournalists.org/blog/2017/10/10/serbiaattacks-against-journalists-must-stop (accessed 14 November 2017)

Fondacija Slavko Ćuruvija (2017). Even tougher media situation prompts EFJ to send international mission to Serbia. http://www.slavkocuruvijafondacija. rs/en/ever-tougher-media-situation-prompts-efj-to-send-internationalmission-to-serbia/ (accessed 19 November 2017)

Gligorijević, J. (2017). Ana Brnabić kao prva lezbijka na čelu srpske Vlade može obradovati samo feministice početnice [Only feminists beginners can be happy with Ana Brnabic as head of Serbian Government]. Forum. http://www.forum.tm/vijesti/ana-brnabic-kao-prva-lezbijkana-celu-srpske-vlade-moze-razveseliti-samo-feministice (accessed 28 september2017)

Hall, M. (2012). Ban on gay rights march could hurt Serbia's EU candidacy.Euractive. https://www.euractiv.com/section/enlargement/news/ban-on-gay-rightsmarch-could-hurt-serbia-s-eu-candidacy/(accessed 1 December 2017) 
N1 (2017). Lično razumem emotivnu reakciju Pokreta socijalista [I personally understand the emotional reaction of the Movement of Socialists]. http://rs.n1info.com/a329533/Vesti/Vesti/Ana-Brnabic-oVulinu-i-Kriku.html (accessed 17 November)

Pokret socijalista Aleksandar Vulin (2017). Dojčinoviću, koliko si novaca dobio od stranaca? [Dojčinović, how much money did you get from foreigners?]. http://pokretsocijalista.rs/news/?id=2635 (accessed 15 November 2017)

RTS (2017). Vučić za RTS: Novoj vladi puna kasa, Ani Brnabić puna podrška [The new Government has a full budget and Ana Brnabić my full support]. http://www.rts.rs/page/stories/sr/story/9/politika/2776545/ intervju-aleksandar-vucic.html (accessed 10 November 2017)

Stojanović, B. (2017). Ana in cotton candy or the tragedy of a civil servant. Peščanik. http://pescanik.net/ana-in-cotton-candy-or-the-tragedy-of-acivil-servant/(accessed 27 September 2017).

Wintour, P. (2017). Ana Brnabić: I don't want to be branded Serbia's gay Prime Minister. The Guardian. https://www.theguardian.com/ world/2017/jul/28/ana-brnabic-serbia-prime-minister-interview (accessed 25 November 2017)

Received: 29 November 2017

Accepted for publication: 31 January 2018 
Андријана Аничић

\title{
ЗАЈЕДНИЧКИ ЈЕЗИК ДИСЦИПЛИНЕ: СМЕШТАҢЕ ПЕДАГОГИЈЕ И АЛТЕРНАТИВНИ СУБЈЕКТИ МОЋИ У СРБИЈИ
}

\begin{abstract}
Сажетак
Овај рад испитује сложеност дискурса који уоквирују именовање Ане Брнабић за министарку, а затим премијерку Србије, у контексту процеса европских интеграција Србије. Теоријски оквир рада заснован је на неколико кључних појмова - „педагогија условљавања”, „хомонационализам” и „сексуално грађанство”. Ови појмови су заступљени у новијим истраживањима (Kahlina 2013; Butterfield 2013; Kulpa 2014; Kahlina 2014) на која се овај рад ослања, а која фокус стављају на динамичан однос између права сексуалних мањина и европских интеграција. Намера ми је да истакнем структурне паралеле између дисциплинујућих механизама присутних како у дискурсу о европским вредностима Европске Уније, тако и у реторици проевропских политичких елита у Србији. У том контексту желим да укажем на то да структурна блискост ова два дискурса твори заједнички језик дисциплиновања који ствара алтернативне субјекте у позицији моћи, којима је укинута агентивност. Предлажем да се сличности које се уочавају између ова два режима дисциплине обухвате појмом „смештање педагогије”, који у овом раду означава процес у коме се режими дисциплине каскадно крећу од Европске Уније ка југоисточној периферији овог блока, узрокујући смештање хијерархијских бинарних подела које карактерише педагошки и инфантилизирајући однос према Другом.
\end{abstract}

Кључне речи: језик дисциплиновања, хомонационализам, sexual citizenship, смештање педагогије 